\title{
Slangs Used by Characters in Movie Script "I Hope They Serve Beer in Hell"
}

\author{
I Putu Agus Ari Purnama*, I Wayan Suardhana, I Nyoman Sedeng \\ English Department, Faculty of Arts, Udayana University \\ [aripurnama994@gmail.com] \\ *Corresponding Author
}

\begin{abstract}
This paper is entitled Analysis of Slangs Used by Characters in Movie Script "I Hope They Serve Beer in Hell". The aims of this study are to identify and classify based on the types of slang word, this paper also described the context of situation of slang used in the movie script I Hope They Serve Beer in Hell. The data source was taken from the movie script I Hope They Serve Beer in Hell (2009). The data collection was conducted through library research method and note taking technique. The first step was done through reading attentively, noting the slang word, and classifying based on the types of slang and context of situation. The collected data were analyzed using descriptive qualitative method with the theory of Allan and Burridge (2006) for types of slang and theory of context of situation proposed by Holmes (2013). The result of analysis shows that there are four types of slang used by character in I Hope They Serve Beer in Hell movie script. Meanwhile, for the context of situation there are four components. The meaning behind each slang words and phrases in I Hope They Serve Beer in Hell movie script depends on the context of situation. Besides, the interpretation of meaning takes important roles in the analysis.
\end{abstract}

Keywords: slang, types of forms of slang, context of situation of slang

\begin{abstract}
Abstrak
Penelitian ini berjudul Analisis Slangs yang Digunakan Oleh Karakter Dalam Naskah Film "I Hope They Serve Beer in Hell". Tujuan dari penelitian ini adalah untuk mengidentifikasi dan mengklasifikasikan jenis slang. Penelitian ini juga menggambarkan konteks situasi bahasa slang yang digunakan dalam naskah film I Hope They Serve Beer in Hell. Data diambil dari skrip film I Hope They Serve Beer in Hell (2009). Data dikumpulkan melalui metode penelitian kepustakaan dan teknik mencatat. Langkah pertama yang dilakukan dengan membaca dengan seksama, mencatat kata-kata slang, dan mengklasifikasikan berdasarkan jenis-jenis slang dan konteks situasinya. Data yang telah terkumpul dianalisis menggunakan metode deskriptif kualitatif dengan teori Allan dan Burridge (2006) untuk jenis-jenis slang dan teori konteks situasi yang dikemukakan oleh Holmes (2013). Hasil dari penelitian ini menunjukkan bahwa ada
\end{abstract}


empat jenis slang yang digunakan oleh karakter dalam skrip film I Hope They Serve Beer in Hell. Sedangkan untuk konteks situasi ada empat komponen. Makna di balik setiap kata slang dan frasa dalam skrip film I Hope They Serve Beer in Hell tergantung pada konteks situasi. Selain itu, interpretasi makna mengambil peran penting dalam analisis.

\section{Kata kunci: slang, bentuk slang, konteks situasi slang}

\section{Background of the Study}

The media that we used to communicate with other people is language. There are two forms of language, written and spoken. It has various meaning when it is used in communication. In the form of spoken language there is a variation of language which is known as slang language.

Chapman (1988) stated slang is the nonlinguistic sort of language and that it mostly ignores the main aim of a language. Chapman also stated that slang words appeared from the special languages of subcultures. The importance of language in establishing social identify is also shown in the case of slang.

Burke (1960) stated, some people are still confused about the term slang and idiom. Slang words may or may not have alternative literal meanings. They may be "made up" words. In other hand, idiom is a phrase that is commonly understood in a given culture or subculture to have a meaning different from its literal meaning.

Movie is one of the media besides song or novel that gives a lot of impact in spreading slangs words worldwide. Usually, teenager is the one that directly affected by slang words influences because it is easier for them to follow or imitate these slangs words. In a movie, movie script is produce to lead the character performance in their play. Movie script is a composed work by screenwriters for a film, game, or TV program. These screenplays can be unique works or adjustments from existing pieces of literary works. Movie script contained movement, activities, articulation, and characters dialogue that is narrate. One of the movie scripts that contained slans is entitled I Hope They Serve Beer In Hell. Sometimes, the slang words are difficult to understand and it would be hard for the audience to follow the story of the movie. This movie script analyzed in order to understand the type of slang words and type of meaning used in this movie script.

\section{Problem of the Study}

There are two problems formulated as follows:

a. What types of slangs are used by characters in data of movie script "I Hope They Serve Beer in Hell'?

b. What context of situation of slangs are used in data of movie script "I Hope They Serve Beer in Hell’?

\section{Aims of the Study}

Regarding the background and problems above, the aims of this study are:

a. To identified and classified based the types of slangs in I Hope They Serve Beer in Hell movie script.

b. To described context of situation of slangs in I Hope They Serve Beer in Hell movie script.

\section{Research Method}

The research methods divided into four steps, they consist of the first, the determination of the data source; second, method and technique of collecting data and method, the third, analyzing data of the "I Hope They Serve Beer in Hell" movie script and the fourth, method and technique of presenting data. 


\subsection{Data source}

The data was taken from "I Hope They Serve Beer in Hell" movie script, which was downloaded from $\mathrm{http}: / /$ screenplaydb/com/film/scripts/I hope they server beer in hell.pdf on Saturday February 2, 2019 at 02.10 P.M. This movie is an American comedy film. This movie is based on the persona and work of writer Tucker Max. He is also co-wrote the screenplay.

The movie is interesting story to be discussed because it has interesting language in this movie called slang, who used by some characters in this movie. It was chosen because it has a lot of slangs varieties in the dialogue many people especially young people like to read it and match with their behavior. Besides that the dominant figure in this movie is adult that usually used slang in their daily life.

\subsection{Method and Technique of Collecting Data}

The method in this study to collecting data was applied documentation method. This study used documentation because the method is appropriate for this study which a library research. This method then followed by some techniques; they are technique of reading attentively with the focus of slang words in the movie script "I Hope They Serve Beer in Hell" by Tucker Max, next the slang words was noted through note-taking technique in order to make the process of identification easier. Finally, the collected data classified based on the types and context of situation of slangs in the movie script "I Hope They Serve Beer in Hell”.

\subsection{Method and Technique of Analyzing Data}

The method of this study is descriptive - qualitative methods. Descriptive method is using word to give information about someone or something in their look or may happen in area which is analyzed. Qualitative method usually requires the data in form of words not using number. The data was analyzed in accordance with the theory of Allan and Burridge (2006) and Holmes (2013) in order to find a certain conclusion, which is the result or findings of this study. There are some techniques to analyze the data source. When reading the movie script, underline the indication of slangs that was used in conversation by the characters and then classified the slang types based on right definition of theory.

\subsection{Method and Technique of Presenting Data}

According to Sudaryanto (1993:145) there are two types of method that can be used to presenting the analyzed data; there are formal and informal methods. Formal method means that the analyzed data are presenting by the table, symbol, diagram, number. While informal method means presenting the result of the analysis by using words and sentences and it purposes to give the explanation to make the readers understand easily. Since the technique of analyzing data was applied descriptive qualitative method which means that the data analyzed by explaining it by words or sentences descriptively, so that is why the informal method was applied in presenting analyzed data. The first step is presenting each type of slangs with their definition followed by the data presentation with full text and the analyzed data in bold type. After that the analyzed data was discussed with informal method in the form of words or sentences description to identify the types of form of slang.

\section{Analysis}

\subsection{Types of Forms of Slangs}

\section{a) Fresh and Creative}

Data 1

Aaron: We've been to strip clubs before 
Tucker: Not like this one, dude. The first time I got a lap dance there, the stripper grabbed my hands and put them on her tits. The second dance, she turned around and basically dry humped me the entire time. She was gorgeous and wasn't even close to being the best one there.

The word dude classified as fresh and creative because this kind of slang is new vocabulary and used in informal variety. It also can be an up to date word in order to describe something in an informal situation. In this case, the word dude uttered by Tucker to call Aaron. The word dude is used for another term to call a man or a friend (male) according to Oxford dictionary.

\section{b) Flippant}

Data 1

Lara: You think you're so clever. I know a hundred insecure asshole just like you.

Aaron: I'm sure your mother's boyfriends were all great guys.

The slang word asshole classified into flippant because that slang language made by two or more in which the words composed not correlated with the denotative meaning. The word asshole has figurative meaning to call a person who does not treat people with respect. The word asshole was uttered by Lara to call Aaron.

\section{c) Imitative}

Data 1

Jade: I don't need a relationship, I already have a boyfriend.

Tucker: Shit baby, I don't want that kind of relationship. I just want to fuck you. I'm a great fuck buddy.

The slang word baby classified as imitative because that slang word imitating the Standard English word: using Standard English word in different meaning or combining two different words. The slang word baby has meaning someone who just born or an infant. The slang word baby in data 21 , based on the statement above it has meaning is a lover; one's sweetheart according to Oxford Dictionary.

\section{d) Clipping}

Data 1

Jack: Wow, mom, look! It's a Duke keychain.

Aaron: Duke was the Field Commander for all the Joes that went into battle. He was my favorite when I was your age.

The slang word mom identified as clipping because the slang word mom is one of variety of slang made by deleting some parts of longer word become shorter form in the same meaning. The slang word mom in data 34 is informal form for "mother". The slang word mom was uttered by Jack.

\subsection{Context of Situation of Slangs}

Data 1

Aaron: We've been to strip clubs before

Tucker: Not like this one, dude. The first time I got a lap dance there, the stripper grabbed my hands and put them on her tits. The second dance, she turned around and basically dry humped me the entire time. She was gorgeous and wasn't even close to being the best one there.

Based on the context of situation, the word dude is use to call a friend because Tucker is talking to Aaron which is they are friend. The participants of the conversation were Aaron and Tucker, they were talked each other. The setting of the conversation above was in 
the bar. The topic of the conversation was Tucker shared his experience when he was visited strip club. The function of their conversation was Tucker wanted to tell Aaron about his experience when he was visited the strip club.

Data 2

Tucker: Not like this one, dude. The first time I got a lap dance there, the stripper grabbed my hands and put them on her tits. The second dance, she turned around and basically dry humped me the entire time. She was gorgeous and wasn't even close to being the best one there.

Aaron: I used to think there was a bright line between a gentleman's club and a brothel. Now you're telling me it's just gray.

The participants of the conversation were Tucker and Aaron. Based on the context of situation, the word tits used on Tucker's statement when he talked to Aaron. The setting of the conversation was in the bar. The topic of the conversation above was Tucker shared an experienced to Aaron when he was visited strip club called Baby Doll. The function of their conversation was Tucker wanted Aaron to know about his experience during visited Baby Doll strip club.

Data 3

Connie: You think I'm hot?

Tucker: Baby, you're so hot, if I were dating you, I'd never leave the house. I'd never even leave your vaginal area, unless I was cumming on your face.

The participants of the conversation were Connie and Tucker. Based on the context of situation, the word cumming on the Tucker's statement above has meaning to describe an orgasm. The setting of the conversation was in the bar bathroom. The topic of the conversation above was Connie asked to Tucker, was she hot or not. The function of their conversation was Tucker tried to seduce Connie to date him.

Data 4

Aaron: Yeah, I'm the misogynist here.

Tucker: It wouldn't be so bad if Durham hadn't passed that ridiculous 'no touch' ordinance. All we can do is sit at a table and look at them.

In this conversation the slang word yeah means "yes". The sentence should be "Yes, I'm the misogynist here." The word yeah in here is use to agreeing that Aaron the misogynist. The participants of the conversation were Aaron and Tucker. The setting of the conversation above was in Campus bar. The topic of the conversation above was they talked about the strip club and the girls in the strip club. The function of their conversation was Aaron claimed himself the misogynist.

\section{Blibliography}

Allan, Keith and Burridge, Kate. 2006. Forbidden Words. New York: Cambridge University Press

Chapman, R. L. 1988. A New Dictionary of American Slang. London: Harper \& Row Publishers Inc.

Kothari, C. R. 1990. Research Methodology: Methods \& Techniques. Jaipur: University of Rajasthan.

Sudaryanto. 1993. Metode dan Aneka Teknik Analisis Bahasa. Yogyakarta: Duta Wacana University Press. 